\title{
Evaluation of the Therapeutic Effect of Syzygium aromaticum Essential Oil in Wistar Rats Infected with Candida albicans - Biochemical and Hematological Study
}

\author{
Djallal Eddine Houari ADLI, Khaled KAHLOULA, Dallal KOURAT, Mostapha BRAHMI*, Sendous \\ Wadjila SOUIDI, Asma NAAR and Miloud SLIMANI
}

Laboratory of Biotoxicology, Pharmacognosy and Biological Valorization of plants (LBPVBP), Department of Biology, Faculty of Sciences, University of Dr MoulayTahar, Saida 20000, Algeria

* Corresponding author: M. Brahmi e-mail: mostapha.brahmi20@gmail.com

RESEARCH ARTICLE

\begin{abstract}
The objective of this study, on the one hand, is to evaluate the impact of Candida Albicans infection $\left(10{ }^{6} \mathrm{CFU}\right.$ per 0.2 $\mathrm{ml}$ of intravenous inoculum) on the biochemical and hematological approaches of adult Wistar rats, on the other hand, to test the efficacy of Syzygium aromaticum essential oil (CEO) in restoring or not the harmful effects of the studied yeast with a daily intraperitoneal injection of $0.1 \mathrm{ml} \mathrm{CEO} / \mathrm{kg}$. The extraction of the essential oil from S.aromaticum by hydro-distillation allowed us to obtain CEO with a yield of $10.18 \%$. Infection of adult rats with Candida albicans by intravenous injection at a concentration of $10^{6} \mathrm{CFU}$ per $0.2 \mathrm{ml}$ of inoculum increased hepatic and renal fungal load. The infection also revealed a disruption of various biochemical parameters, including liver (AST, ALT), kidney (urea, creatinine) biochemical assays, and hematological (white and red blood cells, platelets...); also, the results show a correction in the values of these parameters following the administration of CEO (by an intraperitoneal injection of 0.1 $\mathrm{ml} \mathrm{CEO} / \mathrm{kg} /$ day) compared to those of infected animals. CEO also corrected the shape of the affected blood cells after infection with $C$. albicans.
\end{abstract}

Keywords: Syzygium aromaticum; Candida albicans; Kidney; Liver; hematological parameters.

Received: 10 December 2020

Accepted: 06 May 2021

Published: 14 May 2021

DOI:

10.15835/buasvmcn-vm:2020.0048

\section{INTRODUCTION}

Fungi are a fundamental cause of human infection, and yeasts of the Candida genus are the most pathogenic fungi (Moran et al., 2012). Candida albicans is an opportunistic yeast that usually inhabits the human body (mouth, throat, intestines, and genitourinary tract). It is generally considered a normal part of the human commensal flora (Kohler and al., 2020; Mayer and al., 2013). C.albicans is responsible for several types of infections that can be divided into two groups: Mucosal candidiasis and systemic or disseminated candidiasis, which are the most severe diseases (Drummond and Brown, 2011). It can switch from the commensal to the parasitic state, causing respiratory, digestive and/or vaginal infections (Naglik and al., 2014; Sdoudi and al., 2014).

Herbal medicines have been documented as an essential source for discovering new pharmaceutical molecules used to treat serious illnesses. Many plant species would have pharmacological activities attributable to their phytoconstituents, such as glycosides, saponins, flavonoids, steroids, tannins, alkaloids, terpenes (Batiha and al., 2020). In the same way, green chemistry adopts in its principles all the necessary precautions for the protection of humans and the environment based on green 
extraction technologies (Mnayer, 2014). Clove (Syzygium aromaticum) is used for its culinary and medicinal virtues. Since then, other properties have been discovered, such as an anti-inflammatory, antibacterial, and antianaphylactic and anticandidal effect (Adli et al., 2018; Yassin et al., 2020). Thus, the influential role of cloves as inhibitors of various degenerative diseases is attributed to diverse chemical constituents in high concentrations with antioxidant activity (Astuti et al., 2019; Batiha et al., 2020). Chromatographic analyses of Syzygium aromaticum essential oils identified 26 compounds which mainly represent approximately $80.83 \%$ eugenol, $10.48 \%$ eugenol acetate, $7.21 \% \beta$ caryophyllene (Adli et al. 2017). In the light of these studies, our goal is to investigate the effect of the essential oil of the Syzygium aromaticum plant on Candida albicans infection in adult Wistar rats, according to biochemical and hematological approaches.

\section{MATERIALS AND METHODS}

\section{Extraction of the essential oil}

The researcher realized the present study using the Syzygium aromaticum (clove), a plant) imported from Indonesia (the Moluccan Island). This plant is widely used in Algeria because of its importance in the Algerian culinary tradition, and its use as an herbal medicine. The plant is available at market all year.

The dry and ripe seeds of Syzygium aromaticum were purchased from the local herb market in Saida (Algeria) and were identified and authenticated by an expert taxonomist. A voucher specimen code P-200676 was deposited at the herbarium of the Department of Biology at Saida University (Algeria). The part of the plant used to extract the essential oil is the flower buds of S.aromaticum. The extraction of essential oil has been done by hydro-distillation

\section{Yield Calculation}

The yield of essential oil (EO) is the ratio between the weight of the extracted oil and the weight of the plant material used (Hajammar and al., 2009; Adli and al., 2017). It is calculated as a percentage by the following formula: Y $(\%)=(\mathrm{M} 1$ /M0) $\times 100$

Y: essential oil yield.

M1: quantity of oil extracted expressed in grams (g); M0: quantity of dry matter used for extraction expressed in grams (g)

\section{Preparation of the fungal inoculum:}

In a sterile tube containing sterile saline solution, we have placed colonies of our fungal strain "Candida albicans ATCC 10231" and mixed the suspension. Then using the Malassez cell (Faurie 2019), we prepared a microbial suspension that contains 106 CFU (Colony Forming Unit) of C. albicans (Chilar and Calderone 2009; Lionakis 2010; Liu et al. 2011).

\section{Experimental Design:}

Experiments were carried out on adult Wistar rats, seven months old (obtained from the Department of Biology, Faculty of Sciences, University of Saida) weighing $210 \pm 50 \mathrm{~g}$. The animals were housed with free access to water and food in an animal room, with a 12/12-hour light/dark cycle, at $22 \pm 2{ }^{\circ} \mathrm{C}$. The rats were divided into four groups ( $\mathrm{n}=7 \mathrm{rats}$ ): infected $(\mathrm{Ca})$, infected treated with clove essential oil $(\mathrm{Ca}+\mathrm{EO})$, control-vehicle (Control), control treated with clove essential oil (Control+EO). The number and suffering of animals were minimized by the guidelines of the European Union Directive (2010/63/EU).

Group Ca: The rats were infected with $10^{6} \mathrm{CFU}$ per $0.2 \mathrm{ml}$ of inoculum of the Candida albicans; by intravenous injection into the caudal vein in the tail (Chilar and Calderone 2009; Lionakis 2010; Liu et al. 2011).

Group Ca+EO: After 24 hours of infection, infected rats were treated with $0.1 \mathrm{ml} / \mathrm{kg}$ of Syzygium aromaticum essential oil for eight days intraperitoneally (Adli et al.2018).

Group Control: Rats drinking distilled water.

Group Control+EO: Rats receiving distilled water were treated with $0.1 \mathrm{ml} / \mathrm{kg}$ of Syzygium aromaticum essential oil for 08 days intraperitoneally (Adli et al., 2018).

Infected rats were observed three times a day to monitor any infection's signs and temperature fluctuations.

At the end of the experiment the animals were sacrificed after 12 hours (morning fast), by IP injection with a solution of chloral $(\mathrm{C} 2 \mathrm{H} 3 \mathrm{C} 13 \mathrm{O} 2)$ to $10 \%$. After incision of the abdomen, blood is collected by cardiac puncture in heparin tubes for biochemical analysis and EDTA and tubes for hematological evaluation and dry tubes for blood smears.

\section{Determination of tissue fungal load}

To evaluate the effect of infection induced by $C$. Albicans in adult rats, we determined the fungal tissue load in blood, liver, and kidney using the method of Cihlaret al. (2009).

\section{Biochemical assay}

\section{CRP (C-reactive protein)} (2015).

The CRP assay was done using a kit (Biomaghreb). The CRP level was determined according to the method of Dieusaert 


\section{Determination of the kidney and liver parameters}

The concentrations of kidney markers activities, urea, and creatinine were measured using kits (Chronolab, Spain) according to Kaplan (1984), and creatinine was according to Murray (1984).

The serum samples were used to measure the activity of alanine aminotransferase (ALT), aspartate aminotransferase (AST) according to the methods of Reitman et al. (1957).

\section{Hematological Assay}

\section{Determination of hematological parameters}

Blood taken with EDTA was used for the determination of total red blood cells (RBCs), packed cell volume (PCV), hemoglobin $(\mathrm{Hb})$, mean cell volume (MCV), mean corpuscular hemoglobin $(\mathrm{MCH})$, and platelets count using an automatic cell counter (Mindray BC 3000 plus).

\section{Statistical Analysis}

Results were expressed as mean \pm standard error of the mean (SEM). Data were analyzed by the two-way analyses of variance (ANOVAs). When a significant difference was found, the StudentNewman-Keuls posthoc test was conducted. For all analyses, a difference was considered significant at $\mathrm{p} \leq 0.05$.

\section{RESULTS AND DISCUSSIONS}

The hydro-distillation technique enabled the CEO to be obtained with a yield of $10.18 \%$. This result is not similar to the results of Wenqiang et al. (2006). Who reported a yield of $11.50 \%$, this difference in yield could be attributed to many factors, essentially the origin, the species, the harvest period, the drying time, and the extraction technique of the essential oils (Karousou et al., 2005).

The clinical signs of candidemia or systemic candidiasis are identical to those that characterize episodes of bacteremia and are therefore not specific at all (Bone et al., 1992). There is no specific symptomatology for fungemia and systemic Candida spp. Infections. Fever is observed in approximately $80 \%$ of cases (Develoux et al. 2005; Guery et al., 2009). The liver synthesizes C-reactive protein (CRP) during acute or chronic inflammation in the body. Its level in the blood rises before the onset of inflammation and falls rapidly once the inflammation is treated (Thiébaux, 2019). Besides, its sensitivity, specificity, and short half-life are of significant interest in diagnosing and monitoring infectious diseases (Bouadel, 2010).

During the experiment, we measured the temperature and followed its evolution daily. The results show that the infected rats with C.albicans had a fluctuating temperature, where there was a significant increase during the first 1 st day, 2 nd, 4th, 6th, and 7th. The day after infection compared to control rats $(\mathrm{p}<0.001 ; \mathrm{p}<0.001, \mathrm{p}<0.001, \mathrm{p}<0.001, \mathrm{p}<0.01$, $\mathrm{p}<0.001$ respectively). Otherwise, we recorded a significant decrease in temperature in infected treated rats with CEO compared to infected rats during the 4 th, 6 th, and 7 th day ( $<<0.001, p<0.001, p<0.001$ respectively) (Figure 1), in contrast, $\mathrm{Wu}$ and al. (2019) revealed that a single injection of 25,000 viable C.albicans cells in mice, which is a low-grade transient fungal infection, produced neither fever nor hypothermia.

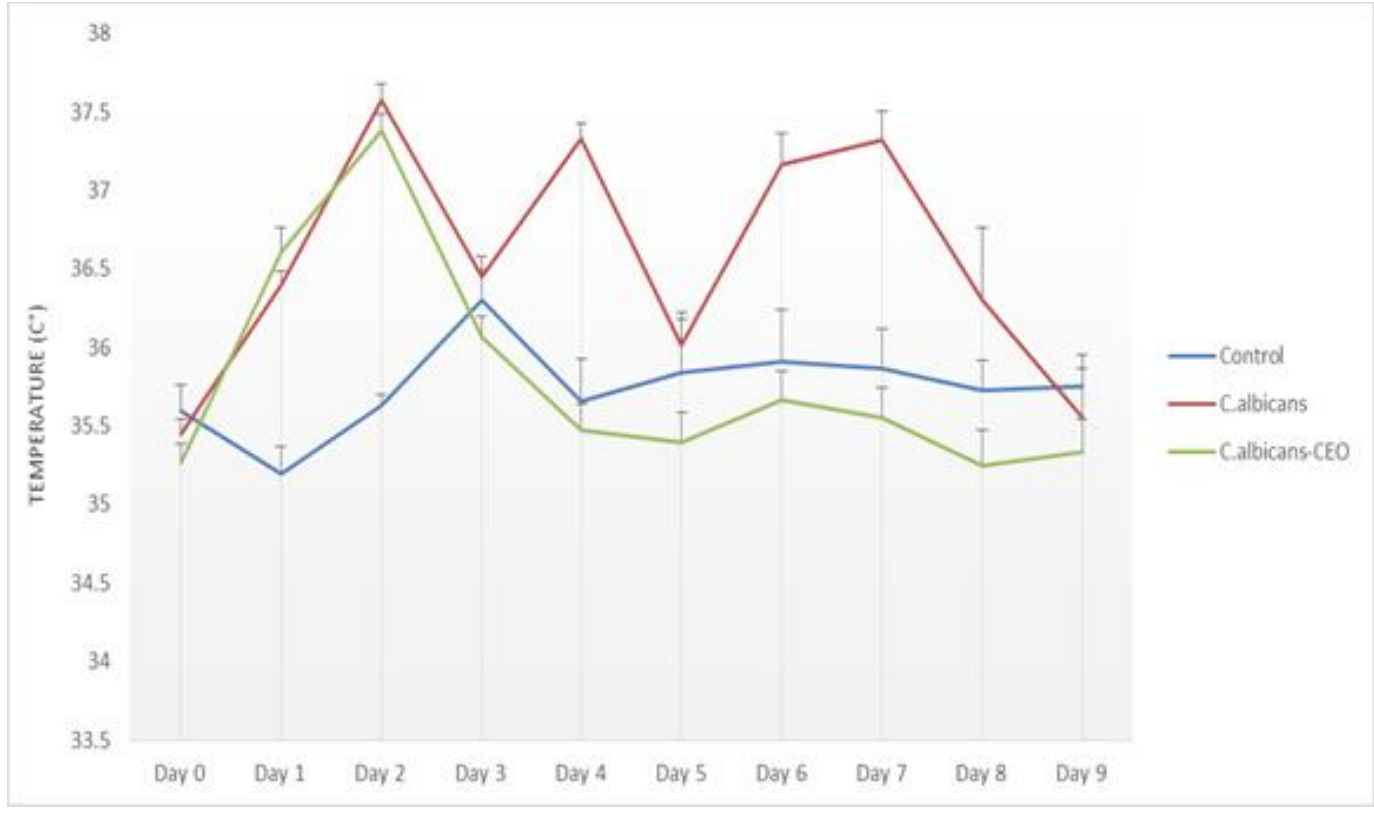

Figure 1. Temperature evolution of control, infected with C. albicans and infected treated rats 
Besides, the CRP assay was positive in the early days of infection, confirming that an inflammatory process started after we injected Candida albicans into the adult rats. Administration of CEO in Candida albicans infected rats resulted in a significant decrease in temperature compared to infected rats; also, CRP was negative in infected CEO-treated rats compared to non-treated infected rats, which could be explained by the antipyretic, anti-inflammatory, and antifungal effect of the essential oil of S.aromaticum (Batiha and al., 2020; Han and Parker, 2017). Pinto et al. (2009) put forward the potential of the CEO as a therapeutic option for fungal infections in humans. Clove has fungicidal characteristics in vitro and in vivo due to its phenolic components, carvacrol and Eugenol (Pulikottil et al., 2015). Clove EO is fungicidal at low concentrations to fluconazole-resistant strains of human pathogenic yeast, such as Candida spp (Lobstein et al., 2017). Pulikottil et al. (2015). indicated that the antifungal activity is due to a considerable reduction in the amount of ergosterol, a specific component of the fungal cell membrane, and it is the action of Eugenol where it attacks the biofilms of C.albicans.

Our results concerning the determination of the fungal tissue load showed that at blood level, the fungal load in rats after 2 days of their C.albicans infection (first sacrifice) is higher than after the other days (second sacrifice, third and fourth sacrifice)(Figure 2).

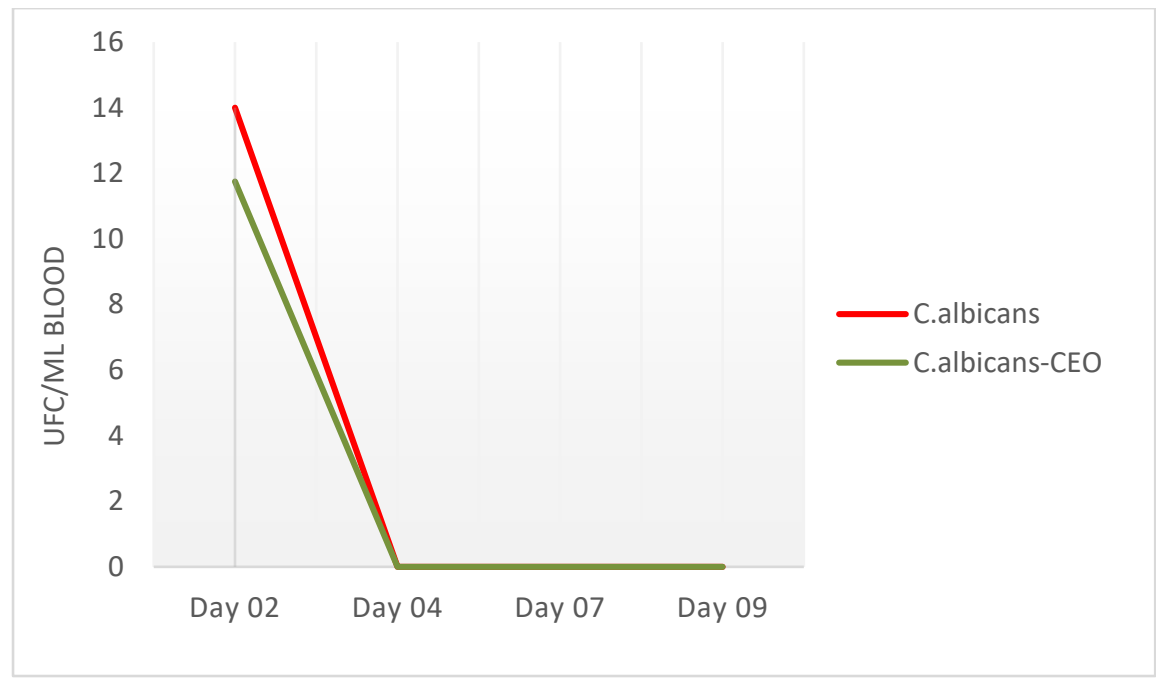

Figure 2. The tissue fungal load in blood in C. albicans infected and infected and CEO-treated rats.

Candida albicans are present in infected rats' liver from the second day of infection (first sacrifice) (96.25 CFU/g). The fungal load increased significantly $(\mathrm{p}<0.001)$ until it reached the highest value after 7 days of $C$. Albicans infection (third sacrifice) $\left(17.26 \times 10^{2} \mathrm{CFU} / \mathrm{g}\right)$, then it decreased significantly $(\mathrm{p}<0.001)$ after 9 days of infection (fourth sacrifice) $\left(9.5 \times 10^{2}\right.$ $\mathrm{CFU} / \mathrm{g}$ ) (Figure 3), and persisted in rising in the kidneys after the 9 the days of infection (Figure 4).

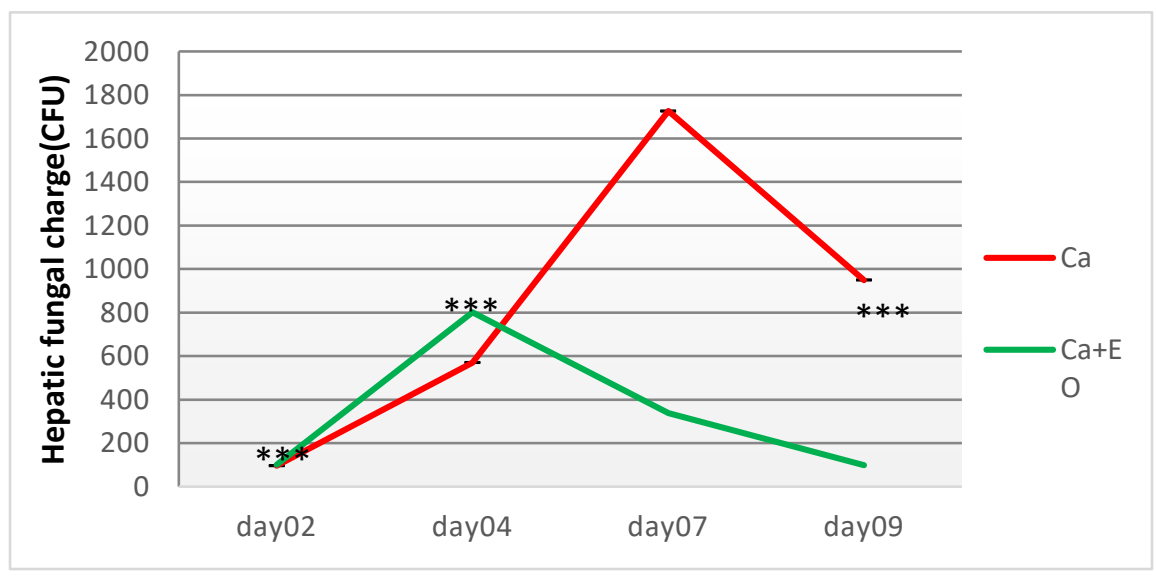

Figure 3. The tissue fungal load in liver in C. albicans infected and infected and CEO-treated rats. 


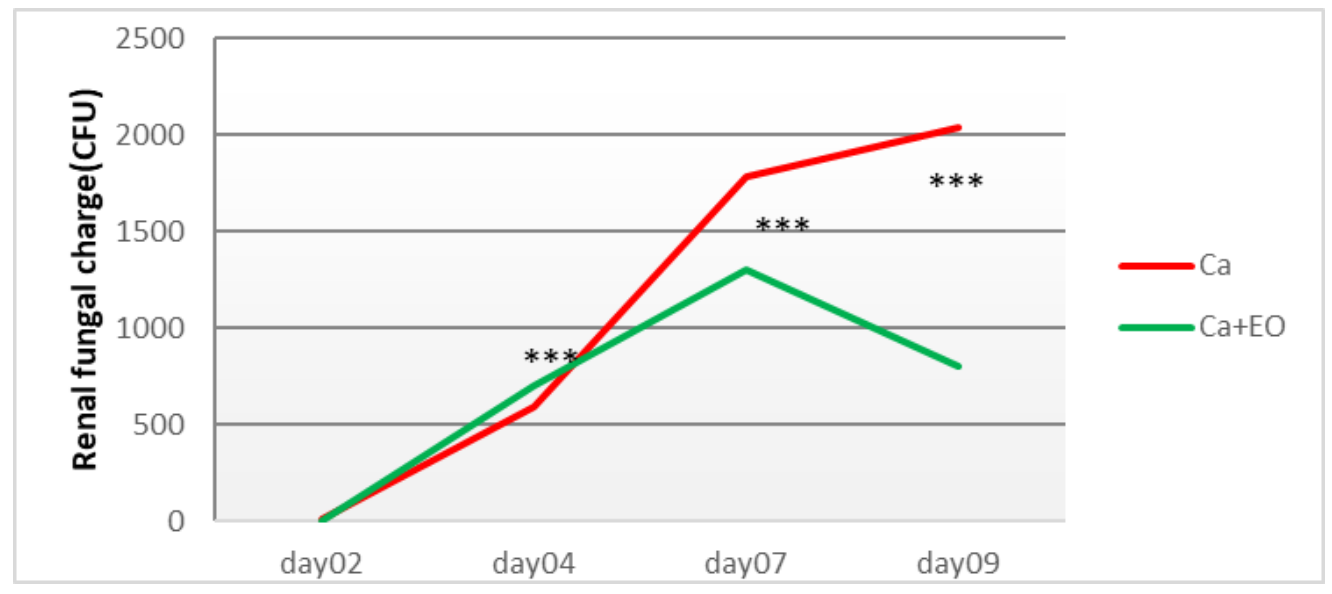

Figure 4: The renal fungal load in C. albicans infected rats and infected and CEO-treated rats.

Lionakis et al. (2010) found that intravenous injection of Candida in mice induced a rapid elimination of $99 \%$ of the fungus from the bloodstream, dissemination to all organs tested within 1 hour after injection, and the initial fungal load in the kidneys and brain increased. Even between the kidney and the brain, a distinct pattern was apparent; the fungal load in the brain peaked on Day 4 and decreased on Day 7, while the renal fungal load continued to increase. Liu et al. (2011) found that after intravenous injection of Candida albicans, the fungal tissue load was first increased in the brain and liver and then decreased throughout the experiment, whereas it was increased in the kidneys throughout. The spectrum of yeast infections due to Candida yeasts is vast, and practically all organs can be affected (Eggimann et al., 2003; Spellerg et al., 2005). Studies by Louria and al (1963) in mice show that renal infection appears to be related to the penetration and growth of the renal tubular lumen. Besides, the inflammatory response in the kidney appeared 4 hours later than in other tissues. The cellular and molecular factors that determine the organ-specific differential control of Candida are still mostly unknown (Lionakis and al, 2010). The cytoskeleton-like organization of hyphae creates a rigid structure whose growth generates forces capable of crossing normal tissues and cell barriers (Defranco et al., 2015). The pathogenesis of Candida albicans comes from its ability to switch from a yeast form to a hyphal form where the yeast form can spread effortlessly through the blood while the hyphal form facilitates tissue invasion (Defranco et al., 2015).

Also, CEO administration showed a difference in the hepatic and renal fungal load where we noticed a significant decrease in fungal load in infected rats treated with $\mathrm{CEO}$ compared to infected rats. The antifungal activity of the $\mathrm{CEO}$ may justify this. S. aromaticum has definite antifungal activity against C. Albicans (Mansourian et al., 2014; Yassin et al., 2020). Eugenol has also been reported to reduce adhesion, biofilm formation, and even alter the morphogenesis of $C$. Albicans (De Paula et al., 2014). Eugenol has been shown to decrease cell viability significantly, and its fungicidal mode of action against $C$. Albicans may be related to its ability to disrupt cell wall integrity by increasing cell permeability, leading to cell leakage (Khan et al., 2013; Shabir et al., 2020).

Urea and creatinine are particular biochemical markers used in the diagnosis of kidney function (Saleh et al., 2012). In kidney dysfunction, urea and creatinine will be secreted in abundance in the blood (Nwanjo et al., 2005) because of their accumulation in the kidney. Rats infected with $C$. Albicans had significantly elevated $(\mathrm{P}<0.001)$ uremia and serum creatinine throughout the experiment compared to control rats (Figure 5 and Figure 6).

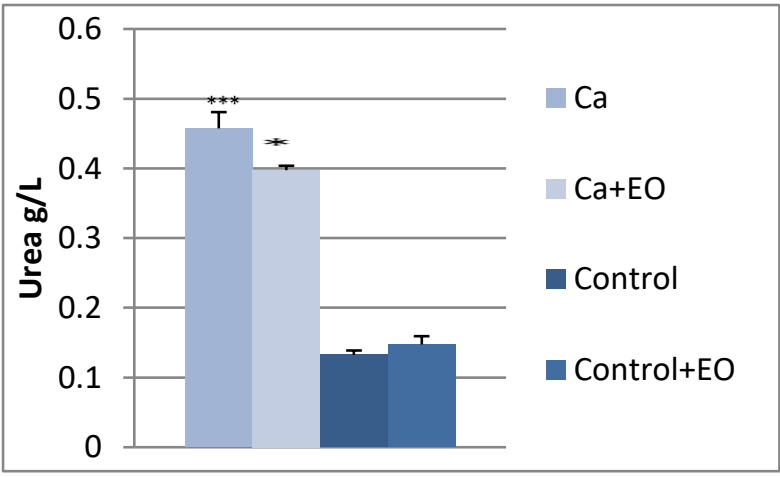

Figure 5. Plasma urea levels in rats: controls, treated controls, C.albicans infected and infected treated with CEO. Values are expressed as mean \pm SEM: ***: $\mathrm{P}<0.001, *: \mathrm{P}<0.05$

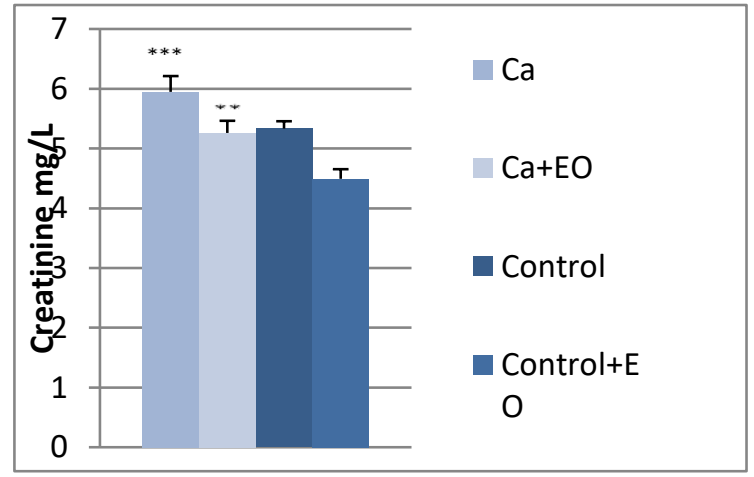

Figure 6. Comparison of creatinemia concentration between rats: controls, treated controls, C. albicans infected and infected treated with CEO. Values are expressed as mean \pm SEM: ***: $\mathrm{P}<0.001$, **: $\mathrm{P}<0.01$ 
Shin et al. (2014) reported an increase in urea and creatinine levels in mice infected with a pathogenic strain of C.albicans (SC5314) (106CFU) that resulted in renal dysfunction and chronic renal failure. Renal lesions were evaluated in mice following systemic administration of C.albicans (Shin et al., 2014). Mice were inoculated intravenously with graduated doses of Candida albicans, and observations were made on mortality. The study showed an increase in urea and creatinine levels (Ryley and al., 1988). The principal cause of mortality from C.albicans infection is candidiasis disseminated by fungal growth in the kidneys and kidney damage (Parker and al., 1976).

On the other hand, after treatment with CEO in infected rats, a decrease in urea and creatinine was noted. The efficacy of CEO in the kidneys may have been due to the presence of chelating compounds such as eugenol (Nassar et al., 2007; Said et al., 2011). Studies suggest that cloves improve kidney function and correct dysfunction in chronic kidney disease (Luvuno et al., 2016). Said et al. (2011) also showed that Eugenol reduces gentamicin-induced tubular necrosis in the kidneys and offers protection against renal failure by acting as an antioxidant.

The liver is an organ that plays an essential role in maintaining the body's homeostasis (Denen and al., 2015). Transaminases (ASATs and ALATs) are sensitive intracellular enzymes and biomarkers secreted into the bloodstream following hepatocyte damage and necrosis (Udenze and al., 2012). Liver damage can be assessed by measuring transaminase activity (ASAT and ALAT) (Bai and al., 2012). We noted that serum transaminase levels (ASAT and ALAT) were significantly increased $(\mathrm{P}<0.001)$ in $C$. Albicans infected rats compared to controls (Figure 7 and Figure 8).

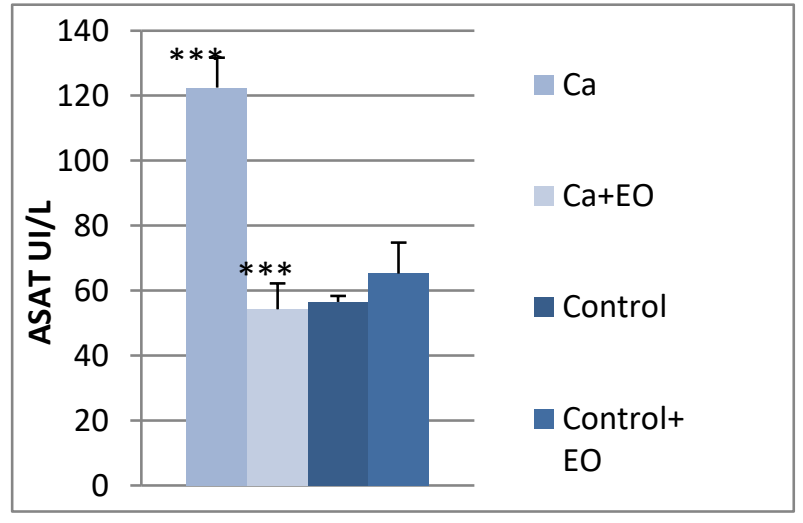

Figure 7. Comparison of serum transaminase levels (ASAT) in rats: controls, treated controls, infected with C. albicans and infected treated with CEO. Values are expressed as mean \pm SEM: ***: $\mathrm{P}<0.001$

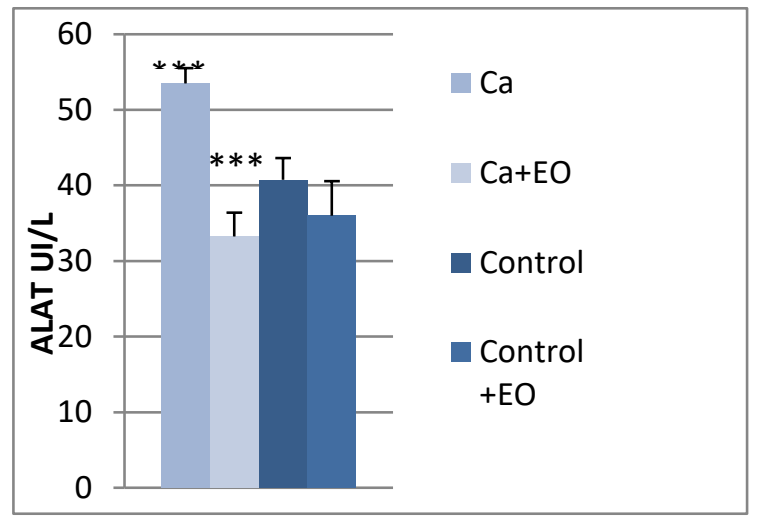

Figure 8. Comparison of serum transaminase (ALAT) levels in rats: controls, treated controls, infected with C.albicans and infected treated with CEO. Values are expressed as mean \pm SEM: ***: $\mathrm{P}<0.001$.

Cardinale et al. (2001) showed that candidiasis causes liver damage with an increase in transaminases. Fungal infection of the liver is usually due to Candida spp (Fiore et al., 2018). Also, there was a significant decrease in liver parameters following CEO administration in infected rats than untreated infected rats. These results are concordant with those of Anbu et al. (2012), who reported that Eugenol decreases plasma transaminases. In rats with hepatic dysfunction, daily intake of $\mathrm{CEO}$ or an EO-containing emulsion of cloves or a microemulsion of Eugenol improved these symptoms in all cases (Alokbi et al., 2014).

We observed a significant increase in the hematological parameters studied: white blood cells (WBCs), red blood cells (RBCs), hemoglobin (HGB), Mean platelet volume (MPV), platelets (PLT), hematocrit (HCT), Mean hemoglobin content (MHC) showed a significant increase in the number of WBCs in infected rats compared to control rats $(\mathrm{P}<0.001)($ Table 1$)$.

Table 1. Comparison of hematological parameters between rats: controls, treated controls, C. albicans infected and infected treated with CEO.

\begin{tabular}{lcccc}
\hline & Control & Control+EO & Ca & Ca+EO \\
\hline WBCs.10 $/ \boldsymbol{\mu l}$ & $7.08 \pm 0.02$ & $5.40 \pm 0.58$ & $10.70 \pm 0.12^{* * *}$ & $7.45 \pm 0.10^{* * *}$ \\
\hline RBCs.10 $/ \boldsymbol{\mu l}$ & $7.53 \pm 0.01$ & $7.23 \pm 0.01$ & $8.19 \pm 0.44$ & $7.88 \pm 0.56$ \\
\hline HGB g/dl & $12.95 \pm 0.03$ & $13.15 \pm 0.14$ & $14.90 \pm 0.52^{* * *}$ & $13.15 \pm 0.55^{* *}$ \\
\hline MPV Fl & $7.05 \pm 0.03$ & $6.85 \pm 0.03$ & $6.65 \pm 0.14^{* *}$ & $7.00 \pm 0.04^{* *}$ \\
\hline PLT.10 $/ \boldsymbol{\mu l}$ & $451.50 \pm 0.87$ & $745.00 \pm 26.56^{* * *}$ & $835.00 \pm 1.15^{* * *}$ & $544.50 \pm 2.6^{* * *}$ \\
\hline HCT \% & $39.25 \pm 0.10$ & $39.90 \pm 0.87$ & $44.65 \pm 1.07 * *$ & $40.55 \pm 1.93^{*}$ \\
\hline MHC pg & $16.93 \pm 0.05$ & $16.85 \pm 0.03$ & $16.60 \pm 0.57$ & $16.55 \pm 0.09$ \\
\hline
\end{tabular}

The values are expressed in mean $\pm \operatorname{SEM}(* * *: \mathrm{P}<0.01, * *: \mathrm{P}<0.01, *: \mathrm{P}<0.05)$ 
Blood is a complex of microorganisms and a hostile environment composed of several cell types and immunoreactive molecules to which C.albicans must adapt and respond (Fradin et al., 2005). Blood cells significantly influence the pattern of C.albicans gene expression in the blood (Fradin et al., 2003). Individual inflammatory responses have evolved to combat fungi that grow along epithelial surfaces. Careful dissection of allergic mucosal inflammatory responses has revealed that the characteristic granulocytes (eosinophils), cytokines (interleukin IL-5 and IL-13), and T effector cells (T helper type 2 (Th2) cells; Th17) are potent fungicides or at least necessary for optimal fungal clearance at mucosal sites in vivo (Porter et al. 2011). Candida expresses adhesions and surface mannoproteins that activate alternative pathways and complement lectins, leading to opsonization and phagocytosis by neutrophils and macrophages. Phagocytosis triggers the assembly of NADPH oxidase and the production of reactive oxygen intermediates, catalyzed by myeloperoxidase (MPO) (De franco et al., 2015). Interactions of fungal cell wall components such as mannoproteins and B-glucan, with phagocyte receptors, facilitate attachment and stimulate cytokine release. The production of cytokines by neutrophil activities, coupled with direct interactions of neutrophils with tissue dendritic cells, triggers the acquired immune response (De franco et al., 2015).

Normal human neutrophils (38 studies) killed 29.0 $7.4 \%$ of $C$. Albicans ingested in 1 hour. Eosinophils and monocytes killed a lower percentage (Lehrer et al., 1969). Iron is an essential element for the growth of Candida. Indeed, as in any living cell, iron and other heavy metals are essential growth factors in fungi. An iron overload has been described during bacterial but also fungal infections. Indeed, most fungi (Candida, Aspergillus, Mucor) secrete siderophores, low molecular weight compounds with a very high affinity for iron ions (Cardinale et al., 2001). The essential oil of Syzygium aromaticum decreased the values of hematological parameters in rats infected with C.albicans, and it significantly corrected the deformation caused by this yeast. CEO reduces inflammation phenomena by inhibiting tumor necrosis factor (TNF) and prostaglandin E2 (PGE2) production and by modulating the action of cyclooxygenase 2 (Cox-2) (Sung et al., 2012; Bachiega et al., 2012). The anti-inflammatory effects of Eugenol have been attributed to its effect in preventing neutrophil/macrophage chemotaxis and prostaglandin synthesis as well as cyclooxygenase II enzyme expression (Pei et al., 2009; Batiha et al., 2020). The antifungal effect of Eugenol and clove oil has been studied against yeasts and filamentous fungi, including various human pathogenic fungi and foodborne fungal species (Chaieb et al., 2007).

\section{CONCLUSIONS}

Our study revealed that infection of adult Wistar rats with Candida albicans caused biochemical and hematological alterations. In addition, our data showed that Syzygium aromaticum essential oil could restore these damages.

Author Contributions: A.D.E and K.D. designed and performed the experiments and also wrote the manuscript; K.K. and S.M. reviewed the manuscript; B.M. performed the biochemical and statistical analysis; S.S and A.N. performed the hematological and statistical analysis. All authors read and approved the final version.

\section{Acknowledgments}

I want to thank all the members of the Laboratory of Biotoxicology, Pharmacognosy and Biological Valorization of Plants (LBPVBP) at the University Dr. Moulay Tahar - Saida - Algeria.

\section{Conflicts of Interest}

The authors declare that there are no conflicts of interest related to this article.

\section{REFERENCES}

1. Adli DEH, Hachem K, Benreguieg M, Brahmi M, Kahloula K, Miloud S, (2018). The efficiency of Syzygium aromaticum essential oil against renal intoxication by lead in rats during development. Bioscience Research 15(3): 2126-2133.

2. Adli DEH, Kahloula K, Slimani M, Brahmi M, Benreguieg M, (2017). Effets prophylactiques de l'huile essentielle de Syzygium aromaticum chez les rats wistar en développement coexposés au plomb et au manganèse. Phytothérapie. Doi:10.1007/s10298-017-1130-3.

3. Al-okbi SY, Mohamed DA, Hamed TE, (2014). Protective effect oil and eugenol microemulsions on fatty liver and dyslipidemia as components of metabolic syndrome. Journal of medicinal food. Doi:10.1089/jmf.2013.0033.

4. Anbu S, Anuradha CV, (2012). Protective effect of eugenol against alcohol-induced biochemical changes in rats. International Journal of Research in Biotechnology and Biochemistry 2(2): 13-18.

5. Astuti R I, Listyowati S, Wahyuni W, (2019). Life span extension of model yeast Saccharomyces cerevisiae upon ethanol derived-clover bud extract treatment. IOP Conf. Ser.:Earth Environ. Sci. ; 299, 012059.doi :10.1088/17551315/299/1/012059

6. Bachiega TF, de Sousa JP, Bastos JK, Sforcin JM, (2012). Clou de girofle et.l'eugénol à des concentrations non cytotoxiques exerce une action immunomodulatrice / anti inflammatoire sur la production de cytokines par les macrophages murins. J Pharm Pharmacol. Doi:10.1111/j.2042-7158.2011.01440.x. 
7. Bai H, Kang P, Tatar M, (2012). Drosophila insulin-like peptide-6 (dilp6) expression from fat body extends lifespan and represses secretion of Drosophila insulin-like peptide-2 from the brain. Aging cell. Doi:10.1111/acel.12000.

8. Barbelet S, (2015) . Le giroflier : historique, description et utilisations de la plante et de son huile essentielle. Université de lorraine. Faculté de pharmacie. https://hal.univ-lorraine.fr/hal-01732523.

9. Batiha GES, Alkazmi LM, Wasef LG, Beshbishy AM, Nadwa EH, Rashwan EK, (2020). Syzygium aromaticum L.(Myrtaceae): Traditional uses, bioactive chemical constituents, pharmacological and toxicological activities. Biomolecules. Doi: 10.3390/biom10030352.

10. Bone RC, Balk RA, Cerra FB, Dellinger RP, Fein AM., Knaus WA, Sibbald WJ, (1992). Definitions for sepsis and organ failure and guidelines for the use of innovative therapies in sepsis. Chest. Doi:10.1378/chest.101.6.1644.

11. Bouadel N, Hssaida R, (2010). L'apport des marqueurs biologiques (CRP et globules blancs) dans le diagnostic de l'infection bactérienne aux urgences A propos de 100 cas.

12. Cardinale V, (2001). Les candidoses vaginales recidivantes a Candida albicans (Doctoral dissertation, UHP-Université Henri Poincaré). HAL Id : hal-01732305, version 1.

13. Chaieb K, Hajlaoui H, Zmantar T, Kahla-Nakbi AB, Rouabhia M, Mah-douani K, Bakhrouf A, (2007). The chemical composition and biological activity of clove essential oil, Eugenia caryophyllata (Syzigium aromaticum L.Myrtaceae): a short review. Phytother. Res. Doi:10.1002/ptr.2124.

14. Chilar R, Calderone Ri, (2009). Candida albicans, methods and protocols, methods in molecular biology499. Doi:10.1007/978-1-60327-151-6_17.

15. De Franco E, Flanagan SE, Houghton JA, Allen HL, Mackay DJ, Temple IK, Hattersley AT, (2015). The effect of early, comprehensive genomic testing on clinical care in neonatal diabetes: an international cohort study. The Lancet. Doi:10.1016/S0140-6736(15)60098-8.

16. De Paula SB, Bartelli TF, Di Raimo V, Santos JP, Morey AT, Bosini MA, Yamada-Ogatta SF, (2014). Effect of eugenol on cell surface hydrophobicity, adhesion, and biofilm of Candida tropicalis and Candida dubliniensis isolated from oral cavity of HIV-infected patients. Evidence-Based Complementary and Alternative Medicine. Doi:10.1155/2014/505204.

17. Denen A, Samuel OO, Joseph E, Egesie UG, Ejike DE, (2015). Effects of ethenol extract of Garcinia kola biochemical markers of liver function of Wistar rats. 4(5): 05-08. ISSN (Online): 2319 - 6718, ISSN (Print): 2319 - 670X.

18. Develoux M, Bretagne S, (2005). Candidoses et levuroses diverses. EMC-Maladies Infectieuses 2, 119-139. Doi:10.1016/j.emcmi.2005.04.001.

19. Dieusaert P, (2015). Guide pratique des analyses médicales, 6e éd. MALOINE.

20. Drummond RA, Brown GD, (2011). The role of Dectin-1 in the host defence against fungal infections. Current opinion in microbiology. Doi: 10.1016/j.mib.2011.07.001.

21. Eggimann P, Garbino J, Pittet D, (2003). Epidemiology of Candida species infections in critically ill non-immunosuppressed patients. Lancet. Infect. Doi:10.1016/S1473-3099(03)00801-6.

22. Fiore M, Cascella M, Bimonte S, Maraolo AE, Gentile I, Schiavone V, Pace MC, (2018). Liver fungal infections: an overview of the etiology and epidemiology in patients affected or not affected by oncohematologic malignancies. Infection and drug resistance. Doi:10.2147/IDR.S152473.

23. Fradin C, De Groot P, MacCallum D, Schaller M, Klis F, Odds FC, Hube B, (2005). Granulocytes govern the transcriptional response, morphology and proliferation of Candida albicans in human blood. Molecular microbiology. Doi:10.1111/j.1365-2958.2005.04557. x.

24. Fradin C, Kretschmar M, Nichterlein T, Gaillardin C, Enfert C, Hube B, (2003). Stage-specific gene expression of Candida albicans in human blood. Molecular microbiology. Doi:10.1046/j.1365-2958.2003.03396. x.;

25. Guery BP, Arendrup MC, Auzinger G, Azoulay É, Sá MB, Johnson EM, Venditti M, (2009). Management of invasive candidiasis and candidemia in adult non-neutropenic intensive care unit patients: Part II. Treatment. Intensive care medicine. Doi:10.1007/s00134-008-1339-6.

26. Haj Ammar A, Zagrouba F, Romdhane M, Abderrabba M, (2009). Extraction de l'Huile Essentielle de Myrte (Myrtus communis L.) Provenant de la Tunisie par Hydrodistillation. In International Symposium on Medicinal and Aromatic Plants-SIPAM. DOI: 10.17660/ActaHortic.2010.853.28.

27. Han X, Parker TL, (2017). Anti-inflammatory activity of clove (Eugenia caryophyllata) essential oil in human dermal fibroblasts. Pharm. Biol. Doi:10.1080/13880209.2017.1314513.

28. Karousou R, Koureas DN, Kokkini S, (2005). Essential oil composition is related to the natural habitats: Corido Thymus capitatus and Satureja thymbra in Natura 2000. Phytochemistry 66:2668-73.

29. Khan MS, Ahmad I, Cameotra S, (2013). Phenyl aldehyde and propanoids exert multiple sites of action towards cell membrane and cell wall targeting ergosterol in Candida albicans. AMB Express. Doi:10.1186/2191-0855-3-54.

30. Köhler JR, Acosta-Zaldívar M, Qi W, (2020). Phosphate in Virulence of Candida albicans and Candida glabrata. Division of Infectious Diseases. Boston Children's Hospital/Harvard Medical School, USA. Doi:10.3390/jof6020040.

31. Lehrer RI, Cline MJ, (1969). Interaction of Candida albicans with human leukocytes and serum. Journal of bacteriology. DOI: 10.1128/JB.98.3.996-1004.1969.

32. Lionakis MS, Lim JK, Lee CCR, Murphy PM, (2011). Organ-specific innate immune responses in a mouse model of invasive candidiasis. Journal of innate immunity 3(2):180-199. 
33. Liu Y, Mittal R, Solis NV, Prasadarao NV, Filler SG, (2011). Mechanisms of Candida albicans trafficking to the brain. PLoS Pathog. Doi:10.1371/journal.ppat.1002305.

34. Lobstein A, Sophie B, (2017). Huile essentielle de Clou de girofle. Laboratoire d'innovation thérapeutique (UMR 7200), Faculté de pharmacie de Strasbourg. Doi:10.1016/j.actpha.2017.07.012.

35. Louria DB, Brayton RG, Finkel G, (1963). Studies on the pathogenesis of experimental Candida albicans infections in mice. Sabouraudia. Doi:10.1080/00362176385190431.

36. Luvuno M, Mbongwa HP, Khathi A, (2016). The effects of Syzygium aromaticum-derived triterpenes on gastrointestinal ghrelin expression in streptozotocin-induced diabetic rats. African Journal of Traditional, Complementary and Alternative Medicines 13(4): 8-14. eISSN: 0189-6016.

37. Mansourian A, Boojarpour N, Ashnagar S, Beitollahi JM, Shamshiri AR, (2014). The comparative study of antifungal activity of Syzygium aromaticum, Punica granatum and nystatin on Candida albicans; An in vitro study. Journal de mycologie medicale. Doi: 10.1016/j.mycmed.2014.07.001.

38. Mayer FL, Wilson D, Hube B, (2013). Candida albicans pathogenicity mechanisms Virulence. Doi:10.4161/viru.22913.

39. Mnayer D, Fabiano-Tixier AS, Petitcolas E, Hamieh T, Nehme N, Ferrant C, Chemat F, (2014). Chemical composition, antibacterial and antioxidant activities of six essentials oils from the Alliaceae family. Molecules. Doi:10.3390/molecules191220034.

40. Moran GP, Coleman DC, Sullivan DJ, (2012). Candida albicans versus Candida dubliniensis: why is C. albicans more pathogenic. International journal of microbiology. Doi:10.1155/2012/205921.

41. Murray RL, Creatinine, Kaplan A, et al. Clin Chem the C.V. Mosby Co, St Louis, Toronto, Princeton. 1984;1261-1266.

42. Murray RL, (1984). Creatinine in: Clinical Chemistry; Theory, Analysis and Correlation, Pesce (Eds.). CV Mosby Co., St. Louis, pp: 1247-1253.

43. Naglik JR, Richardson JP, Moyes DL, (2014). Candida albicans pathogenicity and epithelial immunity. PLoS Pathog. Doi: 10.1371/journal.ppat.1004257.

44. Nassar MI, Gaara AH, El-Ghorab AH, Farrag A, Shen H, Huq E, Mabry TJ, (2007). Chemical constituents of clove (Syzygium aromaticum, Fam. Myrtaceae) and their antioxidant activity. Revista Latinoamericana de Química 35(3): 47.

45. Nwanjo HU, Okafor MC, Oze GO, (2005). Changes in biochemical parameters of kideny function in rats coadministrated with chloroquine and aspirin. Journal Clinical Science 23: 10-12.

46. Parker JR, McCloskey JJ, Knauer KA, (1976). Pathobiologic features of human candidiasis: a common deep mycosis of the brain, heart and kidney in the altered host. American journal of clinical pathology. Doi:10.1093/ajcp/65.6.991.

47. Pei RS, Zhou F, Xu J, (2009). Evaluation of combined antibacterial effects of eugenol, cinnamaldehyde, thymol, and carvacrol against E. coliwith an improved method. J. Food Sci. Doi:10.1111/j.1750-3841.2009.01287.x.

48. Pinto E, VALE-SILVA L, CAVALEIRO C, (2009). Antifungal activity of the clove essential oil from Syzygium aromaticumon Candida, Aspergillus and dermatophyte species. Journal of medical microbiology. Doi:10.1099/jmm.0.010538-0.

49. Porter PC, Roberts L, Fields A, Knight M, Qian Y, Delclos GL, Corry DB, (2011). Necessary and sufficient role for $\mathrm{T}$ helper cells to prevent fungal dissemination in allergic lung disease. Infection and Immunity. DOI: 10.1128/IAI.05209-11.

50. Pulikottil SJ, Nath S, (2015). Potential of clove of Syzygium aromaticum in development of a therapeutic agent for periodontal disease. A review, SADJ 70 (3): 108 - p115. On-line version ISSN 0375-1562. Print version ISSN 00118516.

51. Reitman S, Frankle S, (1957). A method for determination of plasma GOT and GPT. Am. J. Clin. Path $28,108$.

52. Ryley JF, McGregor S, Lister SC, Jackson K, (1988). Kidney function in experimental systemic candidosis of mice/Die nierenfunktion bei experimenteller systemischer candidose der maus. Mycoses. Doi:10.1111/j.1439-0507. 1988.tb03867. x.

53. Said MM, (2011). The protective effect of eugenol against gentamicin-induced nephrotoxicity and oxidative damage in rat kidney. Fundamental \& clinical pharmacology. Doi:10.1111/j.1472-8206.2010.00900. x.

54. Saleh IA, Gamal AS, Awaad AS, Abd El Raheim MD, (2012) . Anti-inflammatory activity, safety and protective effects of Leptadenia pyrotechnics, Haloxylon salicornicum and Ocharadenus baccatus in ulcerative colitis. Phytopharmacology 2(1): 58-71.

55. Sdoudi K, El Hamoumi R, Chaïb N, El Mdaghri N, Razki A, (2014). Candidoses vaginales à Casablanca : implication des espèces non albicans et particularités étiologiques. European Scientific Journal 10(18): ISSN1857- 7431.

56. Shabir OA, Wani MY, Fru P, Ahmad A, (2020). Cellular apoptosis and necrosis as therapeutic targets for novel Eugenol Tosylate congeners against Candida albicans. Scientific reports. Doi:10.1038/s41598-020-58256-4.

57. Shin JC, Jeon YJ, Park SM, Seo KS, Shim JH, Chae JI, (2015). Mechanism underlying renal failure caused by pathogenic Candida albicans infection. Biomedical reports. Doi:10.3892/br.2014.393.

58. Spellberg BJ, Ibrahim AS, Avenissian V, Filler SG, Myers CL, Fu Y, Edwards JE, (2005). The anti-Candida albicans vaccine composed of the recombinant $\mathrm{N}$ terminus of Als $1 \mathrm{p}$ reduces fungal burden and improves survival in both immunocompetent and immunocompromised mice. Infection and immunity. DOI: 10.1128/IAI.73.9.6191-6193.2005. 
59. Sung B, Prasad S, Yadav VR, (2012). Cancer cell signaling pathways targeted by spice-derived nutraceuticals. Nutr Cancer. Doi:10.1080/01635581.2012.630551

60. Thiébaux A, (2019). Protéine C-réactive (CRP), marqueur de surveillance des inflammations. Le Journal des femmes SANTÉ

61. Udenze ECC, Braided VB, Okwesilieze CN, Akuodor GC, Odey MO, (2012). The effects of gavage treatment with Garcinia Kola seeds on biochemical markers of liver functionality in diabetic rats. Annals of biological Research 3(9): 4601-4608.

62. Wenqiang G, Shufen L, Ruixiang Y, et al., (2006). Comparison of essential oils of clove buds extracted with supercritical carbon dioxide and other three traditional extraction methods. Nat Prod Res 20: 992-8.

63. Wu Y, Du S, Johnson JL, Tung HY, Landers CT, Liu Y, Zheng H, (2019). Microglia and amyloid precursor protein coordinate control of transient Candida cerebritis with memory deficits. Nature communications. Doi:10.1038/s41467018-07991-4.

64. Yassin MT, Mostafa AAF, Al-Askar AA, (2020). In vitro anticandidal potency of Syzygium aromaticum (clove) extracts against vaginal candidiasis. BMC Complementary Medicine and Therapies. Doi:10.1186/s12906-020-2818-8. 